Brit. J. industr. Med., 1962, 19, 126.

\title{
BYSSINOSIS IN THE COTTON INDUSTRY OF EGYPT
}

\author{
BY \\ MOSTAFA A. EL BATAWI \\ From the Department of Occupational Health, High Institute of Public Health, Alexandria
}

(RECEIVED FOR PUBLICATION NOVEMBER 15, 1961)

\begin{abstract}
An epidemiological investigation in 11 ginneries representing the ginning industry in Egypt demonstrated the existence of byssinosis among $38.4 \%$ of the workers. Studies of two pressing plants and two card-rooms in Alexandria showed a prevalence of byssinosis of $52.6 \%$ and $26.6 \%$ respectively. The ages of those exposed and the duration of exposure were considered in relation to the prevalence of byssinosis, and it appears that a short duration of exposure in ginning may result in early manifestations of byssinosis at a relatively young age. The interruption of exposure due to seasonal activity in ginning and partially in pressing resulted in a higher proportion of workers with the early stages of the disease. This contrasted with results in carding where exposure is continuous, and a higher proportion of workers have later stages of the disease. This suggests a delay in the progress of the disease due to periodic interruption of exposure.

The comparison between the prevalence of byssinosis and that of chronic bronchitis has shown that these diseases are not necessarily associated, although additional stress due to dust exposure in chronic bronchitis is not denied.
\end{abstract}

Health authorities in Egypt have long been aware that the prevalence of pulmonary disease is excessive among workers exposed to airborne dust in plants in which cotton is processed (A. M. Mahmoud, 1961, personal communication). It had been suggested that byssinosis accounted for some of this disease, but no epidemiological study had been made in this industry prior to the one now reported.

Early in 1960, the Department of Industrial Health of the Ministry of Public Health, the Labour Health Division of the Ministry of Social Affairs and Labour, and the High Institute of Public Health, Alexandria, represented by the Occupational Health Department, formed a committee and invited representatives from interested organizations to review the situation. As a result the High Institute was invited to conduct a field inquiry in the three branches of the cotton industry, which the committee considered to be the most dusty. They were: cotton ginneries, pressing plants, and carding operations in spinning mills.

\section{Industrial Processes}

Cotton cultivation has been a major industry in Egypt during the past two centuries. The cotton is of excellent quality and highly esteemed in countries which import it. Quality depends on the length of the fibre which determines the fineness or coarseness of the material and is related to dustiness. In English mills spinning coarse grades of cotton there is more dust and a higher prevalence of byssinosis than in those spinning fine grades (Roach and Schilling, 1960).

In manufacturing countries such as England, Holland, France, and Belgium the mill workers first open the bales, then card, spin, and weave the cotton. In producing countries such as Egypt and the U.S.A. there are preliminary operations which include the ginning of cotton and pressing it into bales for transport. Egypt not only produces cotton but also manufactures cotton textiles and finished goods.

Therefore, we find in Egypt all three kinds of operation in the cotton industry. There are 95 cotton ginning plants, 35 in Upper Egypt (South) and 60 in Lower Egypt (North). Ginning is a seasonal operation which extends over the six months of the autumn and winter. Thus, those who work in the ginneries are not continuously exposed to cotton dust. The work does not need much skill and many workers are young persons who have just left school at ages from 12 to 20.

The main purpose of ginning is to separate cotton 
seeds from the lint and to free cotton from much of its impurities and plant debris. This is performed in several stages which include mixing, separating the seeds, farfara (which is manual opening of cotton), seed scratching, and finally pressing into bales. The bales are sent either to the spinning and weaving mills or to the pressing plants in Alexandria where the cotton receives further cleaning and mixing to the required qualities. It is then pressed in tight compact bales for export.

All the operations in ginning and pressing are dusty and require a considerable amount of manual labour. The pressing plants in Alexandria work all the year round except for three months in the summer when most of the workers are laid off because at this time there are reduced exports of bales.

Carding, which is a preparatory process in textile plants, may be a very dusty operation, particularly in plants where environmental control is inadequate. Since there is no seasonal interruption in the spinning process, the exposure of card-room workers is continuous throughout the year. However, the type and intensity of airborne dust may be different from those in cotton ginning and pressing plants. The dust may have less impurities and may be lower in concentration in the carding operations.

\section{Objectives}

The first objective of this study was to find out whether byssinosis was a health problem among cotton workers in ginning, pressing, and carding operations. An epidemiological investigation was therefore planned to study the prevalence of this disease in the three processes. Other aims were as follows:-

1. To examine the relation between the occurrence and severity of byssinosis and the degree of environmental dustiness, the chemical composition of dust, and duration of exposure to dust.

2. To observe the effect due to seasonal interruption of work in ginning, and partially in pressing, on the prevalence and clinical course of the disease. This point has merit owing to the fact that it has been claimed that the termination of exposure to dust during the early stages of the disease usually results in complete cure of the symptoms (Gill, 1947; Hunter, 1955). It might therefore be expected that such periodicity of exposure would delay the onset of byssinosis or the development of its more advanced stages.

3. Since Upper and Lower Egypt have different climates, housing conditions, and habits of people, which may be factors influencing pulmonary disease especially chronic bronchitis, it was decided to compare the prevalence of byssinosis, chronic bronchitis, and other chest diseases in these two regions.

The ultimate goal of this inquiry is to prevent pulmonary disease in the cotton industry. The first step is to understand its epidemiology.

\section{Methods}

A pilot study was first performed in two pressing plants in Alexandria during the summer of 1960. The total population at risk numbering 78 was examined (El Batawi and Abdel-Salam, 1961). In Egypt there are approximately 7,600 ginning workers. From the results of this pilot study in pressing plants, and based on the assumption that similar prevalences of the disease in ginning might occur, the size of a representative sample necessary to give a reliable indication of prevalence in the whole ginning industry was calculated. Seven plants in the north and four plants in the south were studied. In each of these every third man on the pay list of the male population distributed in different departments of ginning with variable degrees of exposures was examined. The total number was 323 workers. The female workers in ginning were excluded because they are extremely unstable in holding their jobs.

A similar procedure was followed in selecting the card-rooms for study. However, as a preliminary survey, we examined the total population of 203 workers in two card-rooms in a large textile plant in Alexandria. A control group of 100 Alexandrian workers engaged in manufacturing small electrical appliances was also investigated.

The examination of workers in the three cotton processes was made in a standardized manner with two physicians always checking those subjects in whom byssinosis was diagnosed. From each worker complete social, personal, occupational, and past medical histories were taken. A questionnaire on chest symptoms was followed by a complete physical examination and measurements of height, weight, blood pressure, and vital capacity. In all cases where pulmonary tuberculosis was suspected on clinical grounds, radiographic and sputum examinations were made.

Byssinosis was classified into four grades after Roach and Schilling (1960) and Schilling, Goodman, and O'Sullivan (1952).

Grade 1/2: Occasional chest tightness on exposure to dust on the first day of the working period (i.e. mostly on Saturdays as workplaces are normally closed on Fridays).

Grade 1: Chest tightness and/or difficulty in breathing on exposure to dust during the first day of working period.

Grade 2: Chest tightness and/or difficulty in breathing on exposure to cotton dust during the first and other days of the working period. 
TABLE 1

NUMBERS AND AGE DISTRIBUTION OF WORKERS EXAMINED IN GINNING, PRESSING, AND CARDING

\begin{tabular}{|c|c|c|c|c|c|c|c|c|c|c|c|c|c|}
\hline \multirow{3}{*}{ Process } & \multicolumn{13}{|c|}{ Age (years) } \\
\hline & \multicolumn{2}{|c|}{$<20$} & \multicolumn{2}{|c|}{$20-29$} & \multicolumn{2}{|c|}{$30-39$} & \multicolumn{2}{|c|}{$40-49$} & \multicolumn{2}{|c|}{$50-59$} & \multicolumn{2}{|c|}{60 and over } & \multirow{2}{*}{$\begin{array}{c}\text { Total } \\
\text { Examined }\end{array}$} \\
\hline & No. & $\%$ & No. & $\%$ & No. & $\%$ & No. & $\%$ & No. & $\%$ & No. & $\%$ & \\
\hline $\begin{array}{l}\text { Ginning } \\
\text { Pressing } \\
\text { Carding }\end{array}$ & $\begin{array}{c}62^{*} \\
2 \\
1\end{array}$ & $\begin{array}{r}19 \cdot 2 \\
2.6 \\
0.5\end{array}$ & $\begin{array}{l}90 \\
18 \\
29\end{array}$ & $\begin{array}{l}27 \cdot 9 \\
23 \cdot 1 \\
14 \cdot 3\end{array}$ & $\begin{array}{l}87 \\
22 \\
92\end{array}$ & $\begin{array}{l}26 \cdot 9 \\
28 \cdot 2 \\
45 \cdot 3\end{array}$ & $\begin{array}{l}42 \\
15 \\
58\end{array}$ & $\begin{array}{l}13 \cdot 0 \\
19 \cdot 2 \\
28.6\end{array}$ & $\begin{array}{l}35 \\
18 \\
23\end{array}$ & $\begin{array}{l}10 \cdot 8 \\
23 \cdot 1 \\
11 \cdot 3\end{array}$ & $\begin{array}{l}7 \\
3 \\
0\end{array}$ & $\begin{array}{l}2 \cdot 2 \\
3.8 \\
0\end{array}$ & $\begin{array}{r}323 \\
78 \\
203\end{array}$ \\
\hline Total & 65 & $10 \cdot 8$ & 137 & $22 \cdot 7$ & 201 & $33 \cdot 3$ & 115 & $19 \cdot 0$ & 76 & $12 \cdot 6$ & 10 & 1.6 & 604 \\
\hline
\end{tabular}

*Three were less than 10 years old.

TABLE 2

CHEST DIAGNOSIS AMONG THE WORKERS EXPOSED TO COTTON DUST AND AMONG THE CONTROLS

\begin{tabular}{|c|c|c|c|c|c|c|c|c|c|c|}
\hline \multirow{3}{*}{ Chest Diagnosis } & \multicolumn{6}{|c|}{ Process } & \multirow{2}{*}{\multicolumn{2}{|c|}{ Total Exposed }} & \multirow{2}{*}{\multicolumn{2}{|c|}{ Controls }} \\
\hline & \multicolumn{2}{|c|}{ Ginning } & \multicolumn{2}{|c|}{ Pressing } & \multicolumn{2}{|c|}{ Carding } & & & & \\
\hline & No. & $\%$ & No. & $\%$ & No. & $\%$ & No. & $\%$ & No. & $\%$ \\
\hline $\begin{array}{l}\text { No disease } \\
\text { Byssinosis (all grades) } \\
\text { Bronchitis } \\
\text { Asthma } \\
\text { Tuberculosis } \\
\text { Other }\end{array}$ & $\begin{array}{r}118 \\
124 \\
54 \\
19 \\
5 \\
3\end{array}$ & $\begin{array}{r}36 \cdot 5 \\
38 \cdot 4 \\
16 \cdot 7 \\
5 \cdot 9 \\
1 \cdot 6 \\
0.9\end{array}$ & $\begin{array}{r}20 \\
41 \\
11 \\
2 \\
4 \\
0\end{array}$ & $\begin{array}{l}25 \cdot 6 \\
52 \cdot 6 \\
14 \cdot 1 \\
2 \cdot 6 \\
5 \cdot 1 \\
0\end{array}$ & $\begin{array}{r}51 \\
54 \\
89 \\
8 \\
1 \\
0\end{array}$ & $\begin{array}{l}25 \cdot 1 \\
26 \cdot 6 \\
43 \cdot 9 \\
3 \cdot 9 \\
0 \cdot 5 \\
0\end{array}$ & $\begin{array}{r}189 \\
219 \\
154 \\
29 \\
10 \\
3\end{array}$ & $\begin{array}{r}31 \cdot 3 \\
36 \cdot 2 \\
25 \cdot 5 \\
4 \cdot 8 \\
1 \cdot 7 \\
0 \cdot 5\end{array}$ & $\begin{array}{r}69 \\
0 \\
21 \\
5 \\
2 \\
3\end{array}$ & $\begin{array}{r}69 \cdot 0 \\
0 \\
21 \cdot 0 \\
5 \cdot 0 \\
2 \cdot 0 \\
3 \cdot 0\end{array}$ \\
\hline Total (all cases) & 323 & $100 \cdot 0$ & 78 & $100 \cdot 0$ & 203 & $100 \cdot 0$ & 604 & $100 \cdot 0$ & 100 & $100 \cdot 0$ \\
\hline
\end{tabular}

Grade 3: Disability on account of prolonged chest trouble, with the characteristic history of byssinosis, shown as dyspnoea on slight exertion and reduced vital capacity for the age and height.

The presence of cough with the above symptoms was accepted as an associated complaint in many byssinotics.

Chronic bronchitis was defined as chronic cough with sputum mainly on rising from bed in the morning with occasional acute exacerbation of symptoms.

Bronchial asthma was defined as paroxysmal attacks of severe expiratory dyspnoea occurring at any time independent of exposure.

Dust samples were collected for gravimetric determination of respirable particles, below $7 \mu$, using a specially devised elutriator. The samples were analysed for their content of lipoid material, proteins, minerals, and cellulose. Further environmental sampling and analysis is still being made and the results will be published in a later paper.

\section{Results}

Table 1 shows the age distribution of the workers examined in the three cotton processes. Ginning has a higher proportion of younger workers, as $19.2 \%$ were under 20 years of age. On the other hand, probably due to a greater need for skilled workers, the middle age groups, from 30 to 39 years old, accounted for $45.3 \%$ of the population in carding.

The prevalence of pulmonary disease in the examined cotton workers and in the control group is shown in Table 2. In pressing, 52.6\% had symptoms of byssinosis (all grades). Lower rates of $38.4 \%$ and $26.6 \%$ were found in ginning and carding respectively. Although the environmental dustiness was, in general, slightly higher in ginning than in pressing, the factor of work interruption for approximately six months every year in ginning, which is a much longer period of interruption than in pressing, has probably influenced the situation and reduced the risk of disease. The relatively lower prevalence of byssinosis in card-room workers may be explained by the existence of better environmental conditions in the two card-rooms studied.

The prevalence of bronchitis in pressing and ginning did not seem to show significant differences. In carding workers, a much higher rate of $43.9 \%$ was observed. This may be accounted for by their older age. In addition they smoked tobacco mixed with a product of sugar cane which renders it very irritant to the respiratory tract.

The control group worked in a non-dusty atmosphere. Similar tobacco smoking, however, was prevalent amongst this group, which may explain the relatively higher bronchitis prevalence (21\%) than in ginning $(16.7 \%)$ and pressing $(14 \cdot 1 \%)$.

Table 3 shows the prevalence of byssinosis in different grades in the three processes. The largest number of cases of byssinosis in ginning was in grade $1 / 2$, with 52 cases out of a total of 124 with byssinosis of all grades. In pressing also, the earlier 
grades of the disease, grades $1 / 2$ and 1 , were more prevalent than grade 2 , while in carding most of the cases were in grade 2 . This finding may be explained by the fact that carding operations involve continuous exposure. The mean duration of employment was slightly higher in carding than in pressing or ginning as shown in Table 3 . The effect of interrupted work on the severity of byssinosis may be further examined by comparing the proportion of workers in the various grades of the disease who had more than 10 years at work in cotton dust. Table 4 shows higher proportions in grades $1 / 2$ and 1 in ginning and pressing than in carding; Grade 2 is more prevalent in carding. Environmental dustiness cannot explain this finding since it was observed to be higher in ginning and pressing than in carding (A. A. El Dakhakhney and M. S. AbdelSalam, 1961, personal communication).

Table 5 shows a correlation between grade of disease and duration of employment in ginning. It appears that a worker may be exposed for an average of five years (which is actually five seasons in ginning) before developing early symptoms of byssinosis. As the period of exposure becomes longer, more advanced grades of the disease become more frequent. The five cases with grade 3 byssinosis had an average of 15 years' exposure to cotton dust.

Table 6 shows a comparison between Upper Egypt (South) and Lower Egypt (North) with regard to the prevalence of byssinosis, bronchitis, and other pulmonary diseases in ginning. It was thought that a higher prevalence of bronchitis would be found in the north on account of atmospheric variations of temperature and humidity, the possibility of more air pollution from heavier traffic and industries, and differences in housing conditions and possibly smoking habits. Table 6 supports this expectation. On the other hand it failed to show a similar trend

TABLE 3

PREVALENCE OF DIFFERENT GRADES OF BYSSINOSIS IN THREE COTTON PROCESSES

\begin{tabular}{|c|c|c|c|c|c|c|c|c|c|c|c|c|c|c|}
\hline \multirow{3}{*}{ Process } & \multicolumn{10}{|c|}{ Byssinosis Grade } & \multirow{2}{*}{\multicolumn{2}{|c|}{ No Byssinosis }} & \multirow{2}{*}{\multicolumn{2}{|c|}{ Total }} \\
\hline & \multicolumn{2}{|c|}{$1 / 2$} & \multicolumn{2}{|c|}{1} & \multicolumn{2}{|c|}{2} & \multicolumn{2}{|c|}{3} & \multicolumn{2}{|c|}{ All Grades } & & & & \\
\hline & No. & $\%$ & No. & $\%$ & No. & $\%$ & No. & $\%$ & No. & $\%$ & No. & $\%$ & No. & $\%$ \\
\hline $\begin{array}{l}\text { Ginning } \\
\text { Pressing } \\
\text { Carding }\end{array}$ & $\begin{array}{r}52 \\
7 \\
0\end{array}$ & $\begin{array}{r}16 \cdot 1 \\
9.0 \\
0.0\end{array}$ & $\begin{array}{r}32 \\
16 \\
6\end{array}$ & $\begin{array}{r}9.9 \\
20.5 \\
3.0\end{array}$ & $\begin{array}{l}35 \\
17 \\
47\end{array}$ & $\begin{array}{l}10 \cdot 8 \\
21.8 \\
23.2\end{array}$ & $\begin{array}{l}5 \\
1 \\
1\end{array}$ & $\begin{array}{l}1.5 \\
1.3 \\
0.5\end{array}$ & $\begin{array}{r}124 \\
41 \\
54\end{array}$ & $\begin{array}{l}38 \cdot 4 \\
52 \cdot 6 \\
26 \cdot 6\end{array}$ & $\begin{array}{r}199 \\
37 \\
149\end{array}$ & $\begin{array}{l}61 \cdot 6 \\
47 \cdot 4 \\
73 \cdot 4\end{array}$ & $\begin{array}{r}323 \\
78 \\
203\end{array}$ & $\begin{array}{l}100 \\
100 \\
100\end{array}$ \\
\hline Total & 59 & 9.8 & 54 & 8.9 & 99 & 16.4 & 7 & $1 \cdot 2$ & 219 & $36 \cdot 3$ & 385 & $63 \cdot 7$ & 604 & 100 \\
\hline
\end{tabular}

Average duration of employment for the workers examined: Ginning, eight years; pressing, nine years; carding, nine and a half years.

TABLE 4

DISTRIBUTION OF DIFFERENT GRADES OF BYSSINOSIS AMONG WORKERS EMPLOYED FOR MORE THAN 10 YEARS IN COTTON PROCESSES

\begin{tabular}{|c|c|c|c|c|c|c|c|c|c|c|}
\hline \multirow{3}{*}{ Process } & \multicolumn{8}{|c|}{ Byssinosis Grade } & \multirow{2}{*}{\multicolumn{2}{|c|}{ Total Byssinosis }} \\
\hline & \multicolumn{2}{|c|}{$1 / 2$} & \multicolumn{2}{|c|}{1} & \multicolumn{2}{|c|}{2} & \multicolumn{2}{|c|}{3} & & \\
\hline & No. & $\%$ & No. & $\%$ & No. & $\%$ & No. & $\%$ & No. & $\%$ \\
\hline $\begin{array}{l}\text { Ginning and pressing } \\
\text { Carding }\end{array}$ & $\begin{array}{r}10 \\
0\end{array}$ & $\begin{array}{c}12 \cdot 8 \\
0\end{array}$ & $\begin{array}{r}20 \\
3\end{array}$ & $\begin{array}{r}25 \cdot 6 \\
8 \cdot 1\end{array}$ & $\begin{array}{l}42 \\
33\end{array}$ & $\begin{array}{l}53 \cdot 9 \\
89 \cdot 2\end{array}$ & $\begin{array}{l}6 \\
1\end{array}$ & $\begin{array}{l}7 \cdot 7 \\
2 \cdot 7\end{array}$ & $\begin{array}{l}78 \\
37\end{array}$ & $\begin{array}{l}100 \cdot 0 \\
100 \cdot 0\end{array}$ \\
\hline Total & 10 & $8 \cdot 8$ & 23 & 20.0 & 75 & $65 \cdot 2$ & 7 & 6.0 & 115 & $100 \cdot 0$ \\
\hline
\end{tabular}

TABLE 5

GRADE OF BYSSINOSIS AND DURATION OF EMPLOYMENT IN GINNING

\begin{tabular}{|c|c|c|c|c|c|c|c|c|c|c|c|c|c|}
\hline \multirow{3}{*}{$\begin{array}{c}\text { Duration of } \\
\text { Employment } \\
\text { (years) }\end{array}$} & \multicolumn{10}{|c|}{ Byssinosis Grade } & \multirow{2}{*}{\multicolumn{2}{|c|}{ No Byssinosis }} & \multirow{3}{*}{$\begin{array}{c}\text { Total } \\
\text { (All } \\
\text { Workers) }\end{array}$} \\
\hline & \multicolumn{2}{|c|}{$\frac{1}{2}$} & \multicolumn{2}{|c|}{1} & \multicolumn{2}{|c|}{2} & \multicolumn{2}{|c|}{3} & \multicolumn{2}{|c|}{ Total } & & & \\
\hline & No. & $\%$ & No. & $\%$ & No. & $\%$ & No. & $\%$ & No. & $\%$ & No. & $\%$ & \\
\hline $\begin{array}{l}<6 \\
6-10 \\
>10 \\
\text { Unknown } \\
\text { Total (all years) }\end{array}$ & $\begin{array}{c}38 * \\
6 \\
8 \\
52\end{array}$ & $\begin{array}{r}23 \cdot 5 \\
14 \cdot 6 \\
6 \cdot 7 \\
16 \cdot 1\end{array}$ & $\begin{array}{l}12 \\
10 \\
10 \\
32\end{array}$ & $\begin{array}{r}7 \cdot 4 \\
24 \cdot 4 \\
8 \cdot 4 \\
9 \cdot 9\end{array}$ & $\begin{array}{r}0 \\
5 \\
29 \\
1 \\
35\end{array}$ & $\begin{array}{c}0 \\
12 \cdot 2 \\
24 \cdot 4 \\
\overline{10 \cdot 8}\end{array}$ & $\begin{array}{l}0 \\
0 \\
5 \\
5\end{array}$ & $\begin{array}{l}0 \\
0 \\
4 \cdot 2 \\
\frac{1}{1 \cdot 6}\end{array}$ & $\begin{array}{r}50 \\
21 \\
52 \\
1 \\
124 \\
\end{array}$ & $\begin{array}{c}30 \cdot 9 \\
51 \cdot 2 \\
43 \cdot 7 \\
\overline{38.4}\end{array}$ & $\begin{array}{r}112 \\
20 \\
67 \\
199\end{array}$ & $\begin{array}{l}69 \cdot 1 \\
48 \cdot 8 \\
56 \cdot 3 \\
\overline{61 \cdot 6}\end{array}$ & $\begin{array}{r}162 \\
41 \\
119 \\
1 \\
323\end{array}$ \\
\hline $\begin{array}{l}\text { Mean duration } \\
\text { (years) }\end{array}$ & $5 \cdot 4$ & & $8 \cdot 3$ & & $13 \cdot 6$ & & $15 \cdot 0$ & & $9 \cdot 0$ & & $7 \cdot 5$ & & $8 \cdot 0$ \\
\hline
\end{tabular}

*Five cases with three years' duration of employment. 
TABLE 6

BYSSINOSIS AND OTHER CHEST DISEASES AMONG GINNERS IN THE SOUTHERN (UPPER) AND NORTHERN (LOWER) REGIONS OF EGYPT

\begin{tabular}{|c|c|c|c|c|c|c|}
\hline \multirow{2}{*}{ Chest Diagnosis } & \multicolumn{2}{|c|}{ North } & \multicolumn{2}{|c|}{ South } & \multicolumn{2}{|c|}{ Total (Both Regions) } \\
\hline & No. & $\%$ & No. & $\%$ & No. & $\%$ \\
\hline $\begin{array}{l}\text { No disease } \\
\text { Byssinosis } \\
\text { Bronchitis } \\
\text { Asthma } \\
\text { Other }\end{array}$ & $\begin{array}{r}70 \\
68 \\
42 \\
15 \\
5\end{array}$ & $\begin{array}{r}35.0 \\
34.0 \\
21.0 \\
7.5 \\
2.5\end{array}$ & $\begin{array}{r}48 \\
56 \\
12 \\
4 \\
3\end{array}$ & $\begin{array}{r}39.0 \\
45.5 \\
9.8 \\
3.3 \\
2.4\end{array}$ & $\begin{array}{r}118 \\
124 \\
54 \\
19 \\
8\end{array}$ & $\begin{array}{r}36 \cdot 5 \\
38.4 \\
16 \cdot 7 \\
5.9 \\
2.5\end{array}$ \\
\hline Total (all cases) & 200 & 100 & 123 & 100 & 323 & 100 \\
\hline
\end{tabular}

with regard to byssinosis. Some research workers consider that chronic bronchitis predisposes to byssinosis, and that byssinosis is aggravated in populations where the prevalence of bronchitis is higher. The prevalence of bronchial asthma shows the same trend as bronchitis, with a higher prevalence in the north than in the south.

Environmental dustiness may be heavier, or the grade of cotton may be different, in the south than in the north, which may explain the more frequent occurrence of byssinosis in the south. Nevertheless the lack of association between bronchitis and asthma on one hand and byssinosis on the other is of interest.

\section{Discussion}

There is no doubt that the circumstances of exposure in ginning and pressing are different from those in carding. Dust in the first two operations contains more plant debris, seed husks, and earthy material, and relatively less cotton fibres. In this study, the concentrations of dust in the air were higher in the ginneries than in the card-rooms. On the other hand the workers in ginning have interrupted exposures. The present investigation has shown clearly that byssinosis is present in ginning and pressing, and that interrupted exposure may influence its occurrence and severity.

Two main facts are clearly shown, one is that the disease can start after a period as short as three years (seasons) of exposure to dust. The second is that the course of the disease may be delayed, and the development of more advanced byssinosis may be postponed, where the exposure to dust is interrupted periodically as shown from the comparison between ginning and pressing on one hand and carding on the other (Table 4).

A possible relation between chronic bronchitis and byssinosis has been seriously considered in England, since the reports on byssinosis from other countries, such as Holland and U.S.A., have shown a lower incidence of the disease in their cotton industries. In Lancashire, where the English cotton industry is concentrated, chronic bronchitis is a very common finding among the general population (Goodman, Lane, and Rampling, 1953; Schilling, 1959). The high rates of byssinosis in Lancashire were, therefore, blamed on factors causing a predisposition to chronic bronchitis. The lack of association between the two diseases observed in the present study suggests that chronic bronchitis may not be linked with byssinosis, neither has bronchitis to be necessarily blamed for the existence of byssinosis. It does not exclude the possible additive effect resulting from inhalation of cotton dust in a previously diseased bronchial tree. Also it is not known whether more chronic bronchitis than was found among the ginning workers might have resulted in even higher rates of byssinosis among those workers. Further studies are therefore needed.

I am grateful to Dr. A. Meiklejohn of Glasgow University, whose commentary on the proposed study in ginning plants during his visit to Egypt in 1960 helped us in carrying out this investigation, and for his suggestions in writing this paper. Dr. Yassin El Sadik and Dr. Ossamah El Attar of the High Institute of Public Health, Alexandria, have helped in performing the clinical examinations. I am also grateful to the Department of Industrial Health, Cairo, to Dr. Taha Commaa of Cairo University and to the Department of Biostatistics at the High Institute of Public Health for their kind help and co-operation. I must also express my gratitude to Prof. R. S. F. Schilling for his advice in producing this paper.

\section{REFERENCES}

El Batawi, M. A., and Abdel-Salam, M. S. (1961). Alexandria med. J., 7,355 .

Gill, C. I. C. (1947). Brit. J. industr. Med., 4, 48.

Goodman, N., Lane, R. E., and Rampling, S. B. (1953). Brit. med. $J ., 2,237$, quoted by Schilling, R. S. F. (1959). J. occup.

Hunter, D. (1955). The Diseases of Occupations, p. 921. The

English Universities Press,

Roach, S. A., and Schilling, R. S. F. (1960). Brit. J. industr. Med., 17,1 .

Schilling, R. S. F. (1959). J. occup. Med., 1, 33 Med., 9, 146.
Meod O'Sullivan, J. G. (1952). Brit. J. industr. 